\title{
Ultrastructural aspects of naturally occurring wound in the tunic of two ascidians: Ciona intestinalis and Styela plicata (Tunicata)
}

\author{
Maria Antonietta Di Bella*, Maria Carmela Carbone, Giacomo De Leo \\ Department of Biopatologia e Biotecnologie mediche e forensi, Sezione di Biologia e Genetica, Università degli Studi di Palermo, Italy
}

\section{A R T I C L E I N F O}

\section{Article history:}

Received 10 July 2014

Received in revised form 10 October 2014

Accepted 27 October 2014

Available online 4 November 2014

\section{Keywords:}

Ascidians

Invertebrates

Wound healing

Ultrastructure

\begin{abstract}
A B S T R A C T
Efficient wound healing is essential for all animals from insects to mammals. Ciona intestinalis and Styela plicata are solitary ascidians belonging to urochordates, a subphylum that occupies a key phylogenetic position as it includes the closest relative to vertebrates. Urochordate first physical barrier against invaders is the tunic, an extracellular matrix that is constantly exposed to all kinds of insults. Thus, when damage occurs, an innate immune response is triggered to eliminate impaired tissue and potentially pathogenic microbes, and restore tissue functionality. Ultrastructural aspects of the tunic in the wound healing process of two ascidians are described. In the injured areas, we evidenced thinning of the tunic and areas of low fibre density, dense intratunic bacterial and protozoan population, and inflammatory aspects such as the increase in tunic cells, their aggregates, and phagocytosis. This is the first report on tunic physical wounding occurring in the natural habitat.
\end{abstract}

(ㄷ) 2014 Elsevier Ltd. All rights reserved.

\section{Introduction}

In many organisms surface tissues are in permanent contact with the environment and each animal has evolved repair mechanisms against physical injuries to restore tissue architecture and homeostasis, and to protect the organism from opportunistic infection.

Both the marine sessile species Styela plicata (Styelidae) and Ciona intestinalis (Cionidae) belong to the subphylum tunicates or urochordates that, together with cephalochordates and vertebrates, are included in the phylum chordates (Delsuc et al., 2006). Their integumentary tissue intermediary between the interior and exterior of the animal is the tunic which covers the whole body. The tunic is a multifunctional tissue that provides support and mechanical rigidity. In addition it is a surface barrier exposed to constant microbial attack. It is unique tissue among metazoans, being an extracellular cellulosic matrix coating the epidermis, whose components are proteins associated with carbohydrates including cellulose or cellulose-like polysaccharides (De Leo et al., 1977; Goodbody, 1974; Patricolo and De Leo, 1979). The tunic

\footnotetext{
* Corresponding author at: Dip. Biopatologia e Biotecnologie mediche e forensi, Università di Palermo, Via Divisi 83, 90133 Palermo, Italy. Tel.: +39 91 6554600; fax: +39916554624.

E-mail address: m.antonietta.dibella@unipa.it (M.A. Di Bella).
}

consistency varies from gelatinous to leathery in the different ascidian species, on account of variations in its constituents and the different arrangement of its fibrils. Styela belongs to the suborder of Stolidobranchia and its tunic is leathery and hard, the fibrils form regular bundles which are tightly interwoven and differently oriented, whereas the tunic of $C$. intestinalis, that belongs to the suborder of Phlebobranchia, is a jelly-like coating and the fibrils are arranged in a loose network (De Leo et al., 1981; Di Bella et al., 1998). The outermost fibrous layer of the tunic, called the cuticle, is usually harder than the inner region; the latter is a thick layer of cellulose fibrils, proteins, and polysaccharides embedded in an amorphous matrix that also harbours free cells and is called ground substance or tunic matrix. Several types of free mesenchyme-like cells, known as tunic cells, varying from species to species, have been described. They are involved in various tunic biological functions, such as accumulation of metabolites and inorganic products, elimination of metabolic wastes, pigmentation, defence response, phagocytosis, and allorecognition (Burighel and Cloney, 1997 and references therein; Hirose, 2009a).

The cuticle can be frequently damaged by sands and microorganisms and any rupture must be quickly repaired to prevent microbes from gaining access and spreading throughout the body. It frequently harbours foreign material including cyanobacteria or algal symbionts attached to its external surface, even if hostassociated symbionts can also be located within the tunic matrix of some ascidians (Blasiak et al., 2014; De Leo and Patricolo, 1980; Hirose et al., 2006). Thus, when damage occurs, the tunic must possess repair mechanisms against physical wounding to 

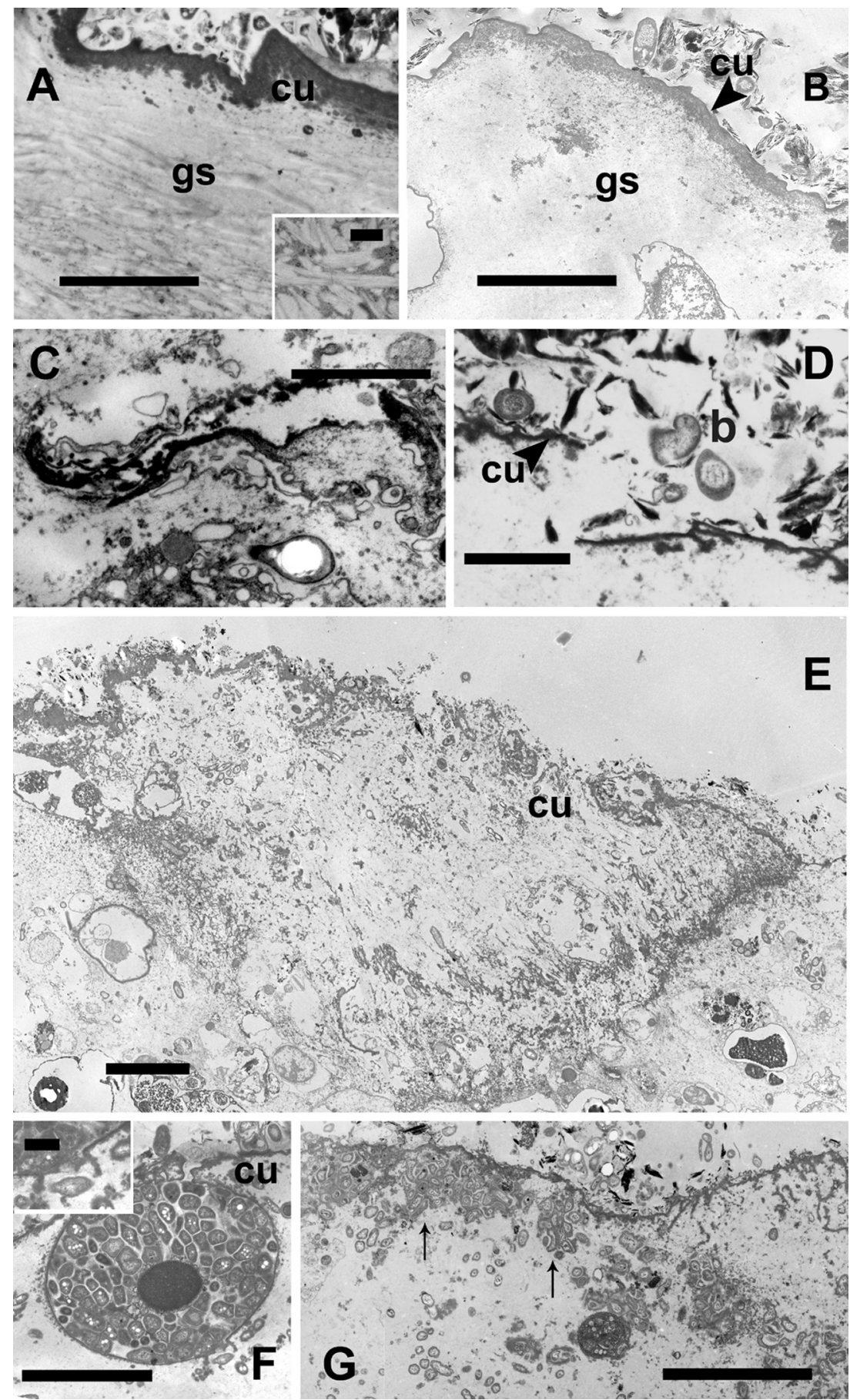

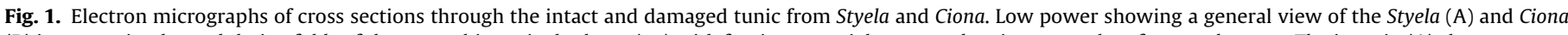

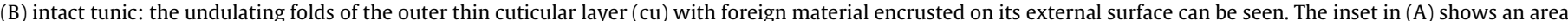

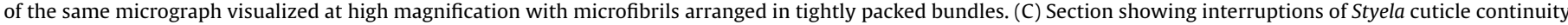

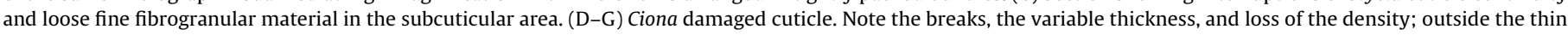

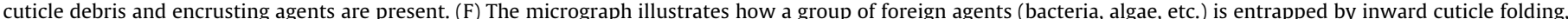

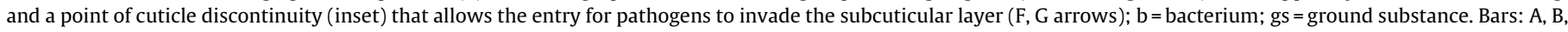
E, F, G $=5 \mu \mathrm{m} ; \mathrm{C}, \mathrm{D}=2.5 \mu \mathrm{m} ; \mathrm{A}, \mathrm{F}$ insets $=0.5 \mu \mathrm{m}$.

re-establish normal architecture. As Ciona and Styela are basal invertebrate chordates lacking adaptative immune systems, tissue damage triggers an innate immune response to protect from infection. As observed during inflammatory-like response experimentally induced, key players in these processes are tunic cells and their products, and haemocytes. In few hours after injection of soluble or particulate materials into the body wall of C. intestinalis, the tunic matrix appears to be densely populated with cells and an inflammatory response including encapsulation and often tissue damage occurs (Di Bella and De Leo, 2000; Parrinello and Patricolo, 1984; Parrinello et al., 1977, 1984); soluble factors, and extracellular components can also collaborate.

The present ultrastructural study aims to describe aspects of wound healing that occur in nature in the tunicates, S. plicata and C. intestinalis and to compare their cellular reactions. 


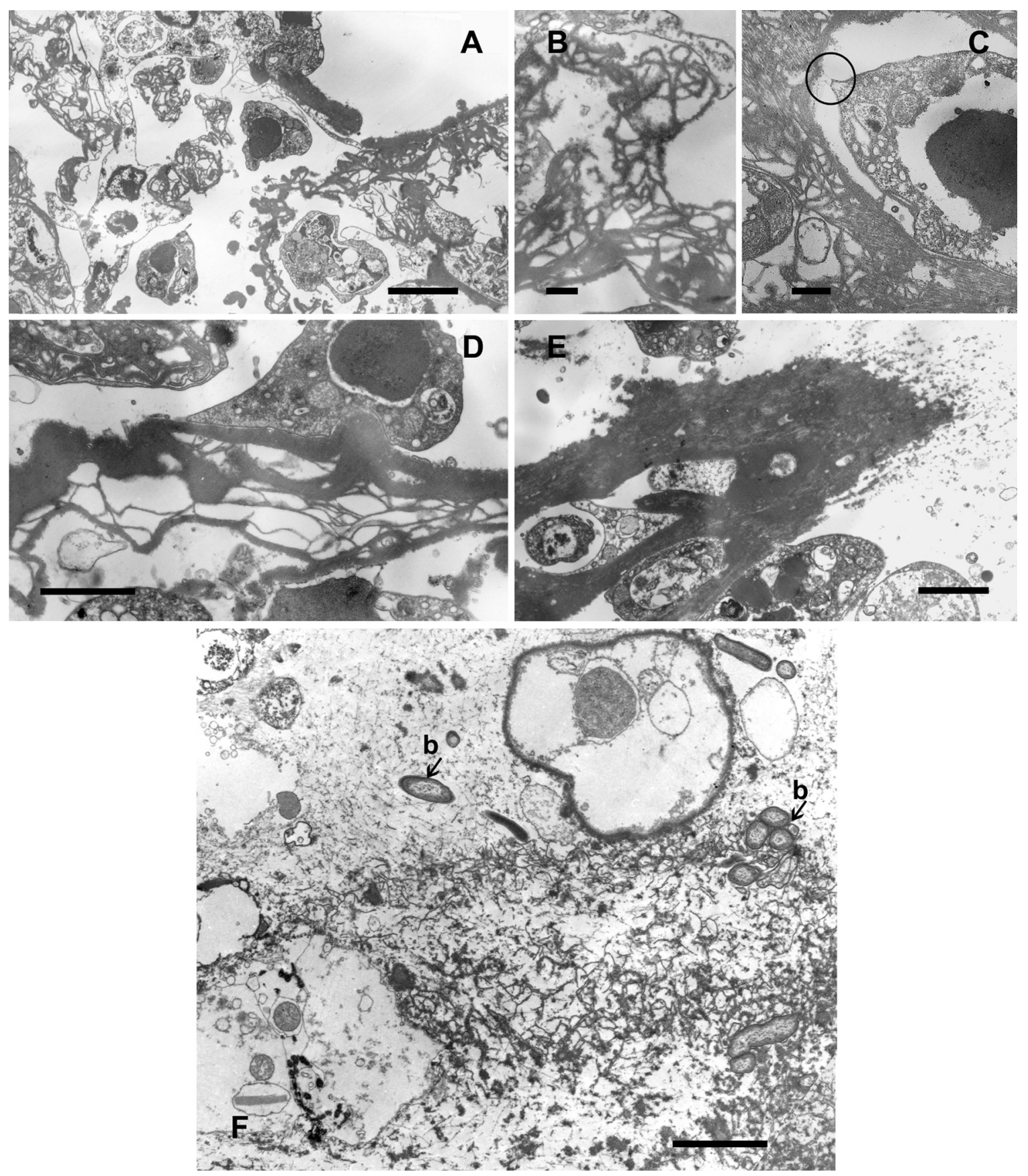

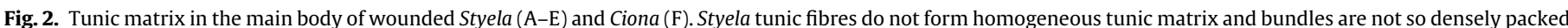

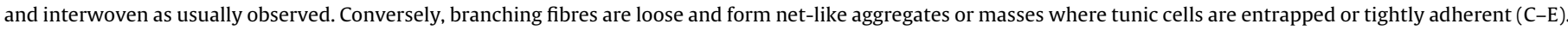

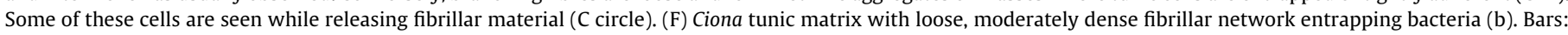
$\mathrm{A}=5 \mu \mathrm{m} ; \mathrm{B}, \mathrm{C}=0.5 \mu \mathrm{m} ; \mathrm{D}, \mathrm{F}=2 \mu \mathrm{m} ; \mathrm{E}=2.5 \mu \mathrm{m}$.

\section{Material and methods}

C. intestinalis adult specimens about $3-5 \mathrm{~cm}$ long were obtained from Stazione Zoologica Anton Dohrn, Naples, Italy. Adult specimens of the ascidian S. plicata collected in the Ganzirri coast lake (Southern Italy), were kept in aerated aquaria at $15-18^{\circ} \mathrm{C}$ until used. Animals were fed daily with various food types including freeze-dried rotifers, green unicellular algae and marine invertebrate artificial diet coraliquid (Sera Heinsberg, Germany).

Pieces of tunic cleaned by gentle brushing to remove debris and fouling organisms were dissected from different regions of the body of apparently healthy specimens. To avoid extensive contractions of the animals, the specimens were anaesthetized by adding MS222 to the medium (final concentration $0.2 \%$ ). Fragments from the tunic body 1-3 $\mathrm{mm}$ long were fixed using the following procedure.

They were placed for $1 \mathrm{~h}$ at $4{ }^{\circ} \mathrm{C}$ in a solution containing $1.5 \%$ glutaraldehyde (Sigma-Aldrich, St. Louis, USA), buffered with $0.05 \mathrm{M}$ sodium cacodylate ( $\mathrm{pH} 7.3$ plus $1.7 \%$ sodium chloride), and postfixed for $1 \mathrm{~h}$ at $4{ }^{\circ} \mathrm{C}$ with $1 \%$ osmium tetroxide in $0.05 \mathrm{M}$ sodium cacodylate at $\mathrm{pH}$ 7.3. All specimens were rinsed briefly and dehydrated in a graded series of ethanol solutions, cleared in propylene oxide and embedded in Epon resin.

Semithin sections were stained with toluidine blue. Ultrathin sections (50-70 nm thick) were stained with uranyl acetate and 
lead citrate and examined under a transmission electron microscope (Philips CM 10), at $80 \mathrm{kV}$.

Negatives were scanned on an Epson Perfection V 700 PHOTO scanner and acquired as TIFF files. All TIFF files were resampled at 300 ppi and subsequently re-sized and optimized for brightness and contrast by using Photoshop (Adobe Systems).

For tunic identification, the nomenclature proposed by De Leo (1992) was followed.

\section{Results}

We found some tunic areas from naïve S. plicata and C. intestinalis where signs of inflammatory reaction were observable in semithin sections. In order to confirm these observations, we carried out an ultrastructural analysis. The electron microscope showed regions of damaged tunic where the architecture was different from that usually observed. To provide the context for considering results, we describe briefly the basic morphology of intact tunic. As previously reported, the tunic consists of a rather thin outer cuticle and a thick ground substance layer where cells are scattered. In both Styela and Ciona, the cuticle is a highly dense structure sufficiently compact to harder the surface of the tunic. It is composed of fibrogranular material that results in a homogenous closely interwoven network (Fig. 1A and B). In S. plicata ground substance, elementary fibrils are densely packed and usually associated to form regular bundles embedded in the amorphous matrix; the bundles are differently oriented and interlaced with each other (Fig. 1A, inset). The innermost zone of $C$. intestinalis tunic is a pale amorphous layer consisting of a network of delicate fibrils (Fig. 1B). Where the cuticle was damaged, there was loss of cuticle continuity and compactness, and the thickness varied so that the tunic matrix was externally exposed. The subcuticular areas consisted of loose fibrillar material and appeared not completely organized (Fig. 1C-E). Entrapment of foreign organisms was seen (Fig. 1F and $G$ ). In the main body of $C$. intestinalis tunic matrix several areas of irregular fibre density were present (Fig. 2F). The S. plicata tunic fibres did not form thick and interlaced bundles as seen in intact samples (Fig. 1A, inset) but branching ribbons not homogeneously packed covered the wound area, fibrous materials were loosely intertwined. Large tightly packed tunic masses were present and several cells were seen entrapped in them (Fig. 2A-E).

The wounded areas appeared with the aspects of inflamed tissue. The distribution pattern of cells was different from the unwounded samples as the cell number was highly increased beneath the cuticle and in the main tunic body both in Styela and Ciona (Fig. 3A and B).

Tunic clear vesicular granulocytes were the cell types most frequently found in Styela wounded tunic. They showed irregular shape and amoeboid aspect as the cellular profile exhibited various protrusions and frequently petaloid features. Their cytoplasm was completely occupied by many vesicles both in the inner and in the peripheral areas (Figs. 3A and 4A, G, L). Cells also showed phagocytic features displaying irregular shape and cell surface often ruffled with filopodia. The cytoplasm often contained vesicles and phagosomes engulfing myelin-like membranes or other cells (Figs. 3A and $4 \mathrm{~B}$ and C). Heterogeneous material (bacteria, algae, cell debris) was consistently observed both within intracellular spaces in phagocytic vacuoles and free around the wound, within the tunic matrix (Figs. 3 and 4N). Some microgranulocytes showing several granules filled with more or less electron-dense material, globular granules or vacuoles with a meshwork of thin filaments inside were also observed (Fig. 4D, M, H). Moreover, several cells were in a degranulating stage. The plasma membrane was interrupted and the cell content appeared released outside the cell. The discharged material seemed to bind to the fine filaments of the tunic matrix

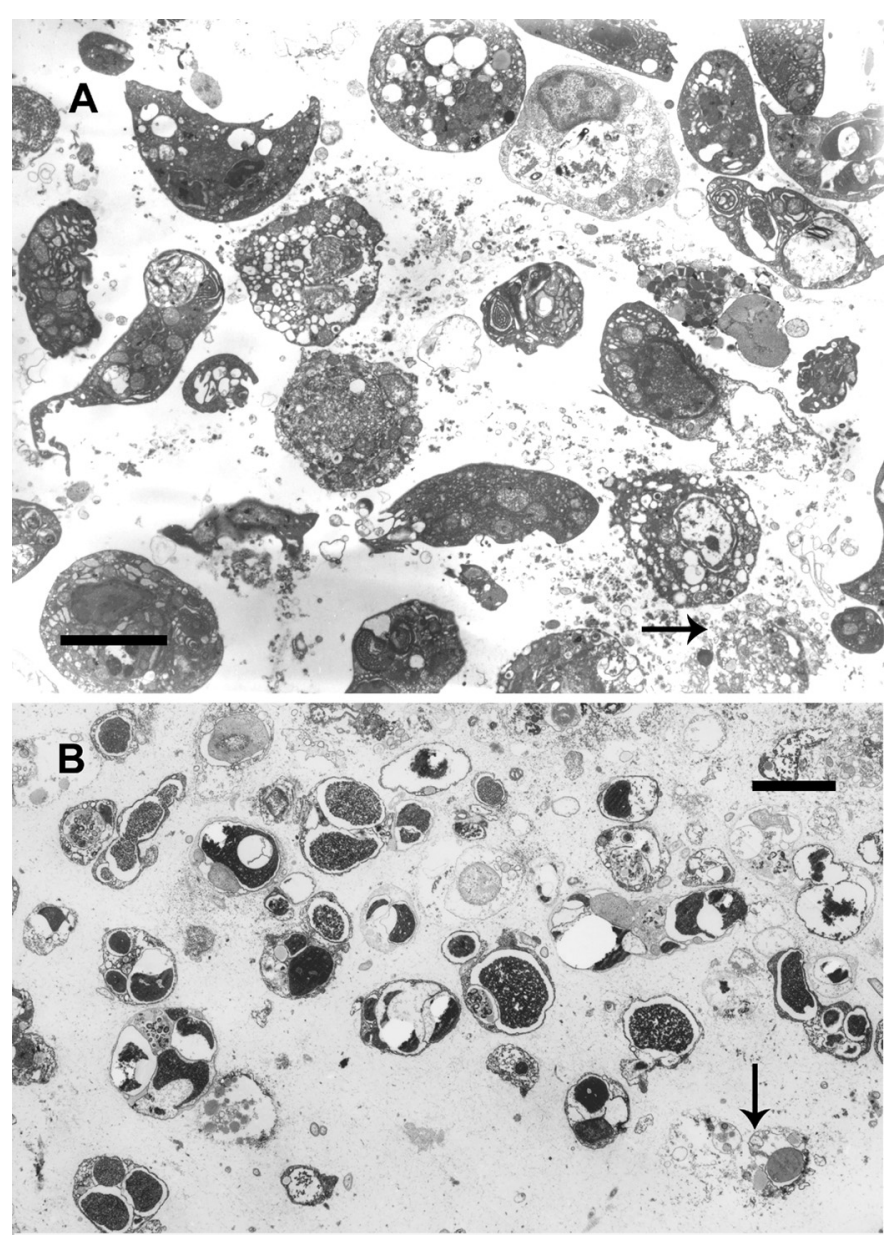

Fig. 3. Micrographs of portions of Styela (A) and Ciona (B) wounded tunic. The number of granulocytes is very high recalling a typical aspect of inflamed tissue. The cells mainly found in Styela tunic are vesicular granulocytes with a characteristic amoeboid feature, and cytoplasm filled with numerous vesicles. Most cells found in Ciona are globular granulocytes. Several cells are degenerating in both Styela and Ciona samples (arrows) Bars: $5 \mu \mathrm{m}$.

that formed net-like structures (Figs. 3 and $4 \mathrm{~F}$ and I). The loss of content and the confluence of vacuoles gave rise to drastic configurational changes so that the cells appeared swollen. The cytoplasm devoid of organelles and the membrane presenting points of discontinuity reduced the cells to ghosts (Fig. 4E).

In the case of $C$. intestinalis, tunic cells observed in these wounded areas were conspicuously globular granulocytes whose shape ranged from round to elongated (Fig. 3). Their cytoplasm was entirely occupied by large globules containing highly dense material and some vesicles in the residual cytoplasm. Confluence of the vacuoles and flaking of the electron-dense vacuolar material were observed (Fig. 5A and B). Some cells presented phago-lysosomes engulfing cellular debris and remnants of foreign or dead matter; moreover, some unilocular granulocytes characterized by the presence of a single, large vacuole containing dark fibrogranular material were also found. They were observed going through progressive modifications, as the large inclusion appeared uniformly filled or losing the compactness and dissolving near the cell membrane (Fig. 5C, D, E, and H). As observed in Styela, evidence of advanced cell degranulation was found in these areas. Gathering of vesicles, cytoplasmic membrane dissolution and extrusion of the electron-dense contents released from the disintegrating cell producing meshwork of thin fibrils around were observed (Figs. 3 and 5F). Finally, one peculiar aspect observed at wound 


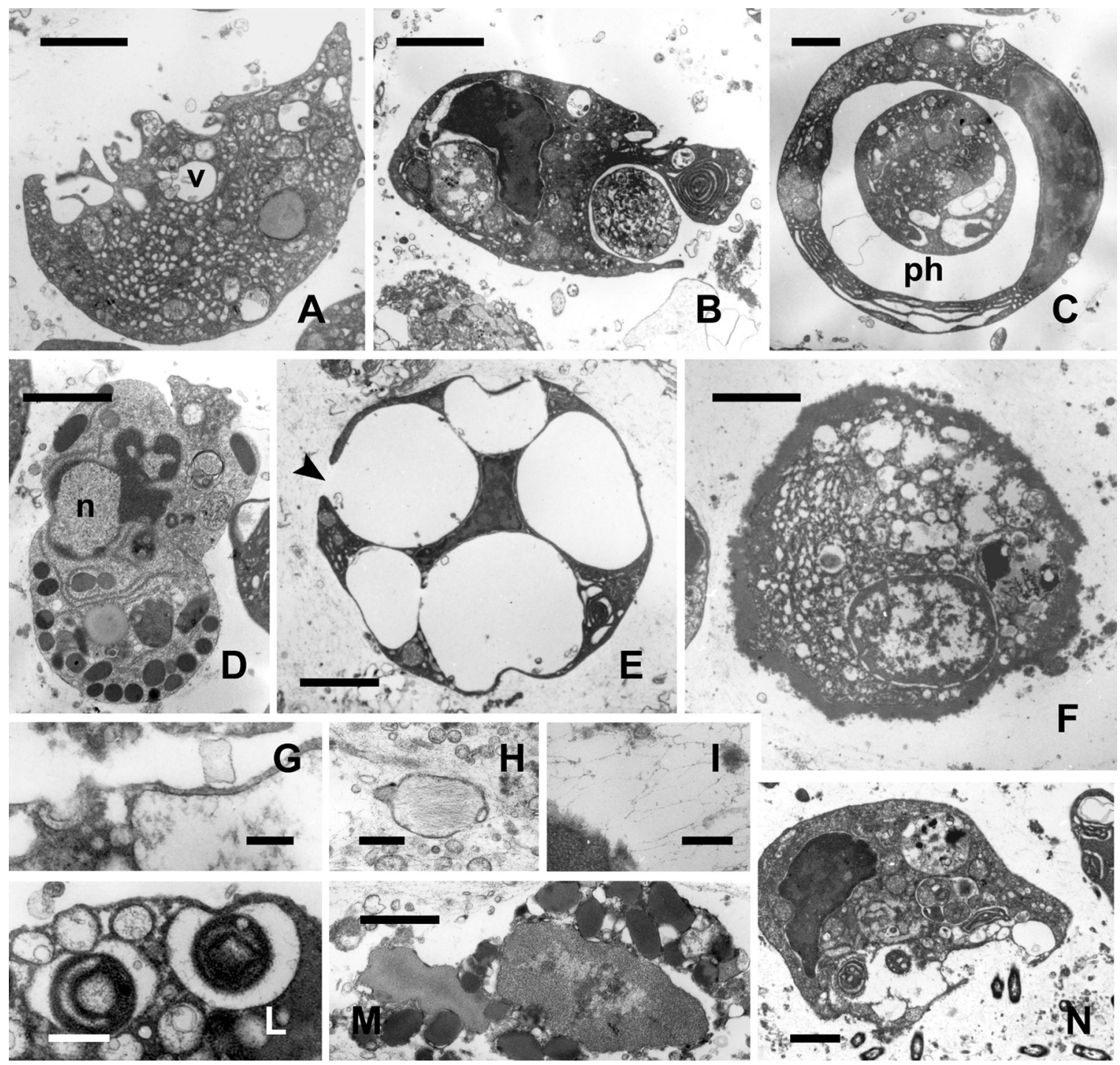

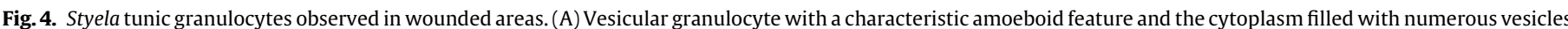

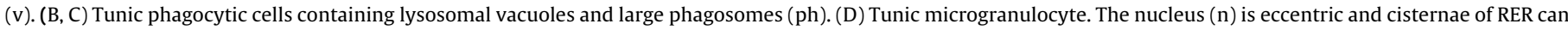

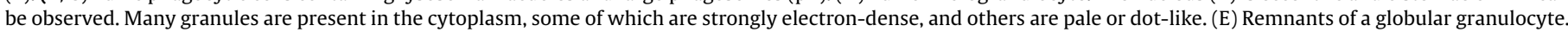

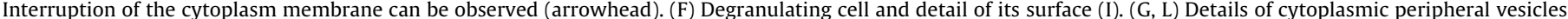

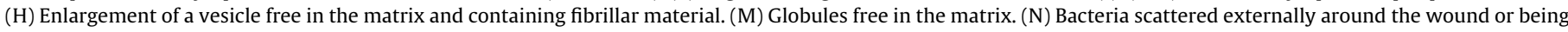
engulfed in digestive vacuoles. Bars: $A, B, D, F=2 \mu \mathrm{m} ; \mathrm{E}=2.5 \mu \mathrm{m} ; \mathrm{C}, \mathrm{M}, \mathrm{N}=1.5 \mu \mathrm{m} ; \mathrm{G}, \mathrm{I}=0.25 \mu \mathrm{m} ; \mathrm{H}, \mathrm{L}=0.5 \mu \mathrm{m}$.

sites was the adhesive morphology of cells that showed extensive membrane contact and seemed to form strong cellular clot (Fig. 6A). Several cells adhering to each other were reduced to simple ghosts as the organelles were lost, the globules and the inclusions were dissolved, intracellular vesicles with debris within, and some large vacuoles engulfing bacteria were often present implying phagocytic activities and clearance of invading microbes (Fig. 6B-D).

\section{Discussion}

Open wounds of the integuments represent an entry port for bacteria and pathogens to invade the open circulatory system of tunicates and the inner tissues, so that tissue damage triggers an innate immune response involving the concerted action of both humoral and cell mediated responses to protect organisms and heal the wound.

In the present study some ultrastructural aspects of wounded tunics of two ascidians $S$. plicata and C. intestinalis are reported.
The most remarkable differences here reported between intact and wounded tunics, are:

a) thinning of the tunic

b) high presence of bacteria and protozoans within the tunic

c) inflammatory aspects

The tunic represents a first line of tunicate defence against pathogens and injury; naturally occurring damage may produce disruption of the continuous cuticle layer with loss of its density and thickness. Thinning of the cuticle and softening of the ground substance were found in diseased tunics from ascidian Halocynthia roretzi with clinical signs of soft tunic syndrome. This infectious disease that often leads to mass mortality is due to a kinetoplastid and causes a difference in the tunic hardness, and presence of areas of low fibre density and interlacement (Hirose et al., 2009c). Similarly, in contrast with the intact specimens, the exposed Styela tunic areas evidenced the absence of thick interlacing fibres bundles, but showed rather fibrous material loosely packed or ribbon of fibrils 

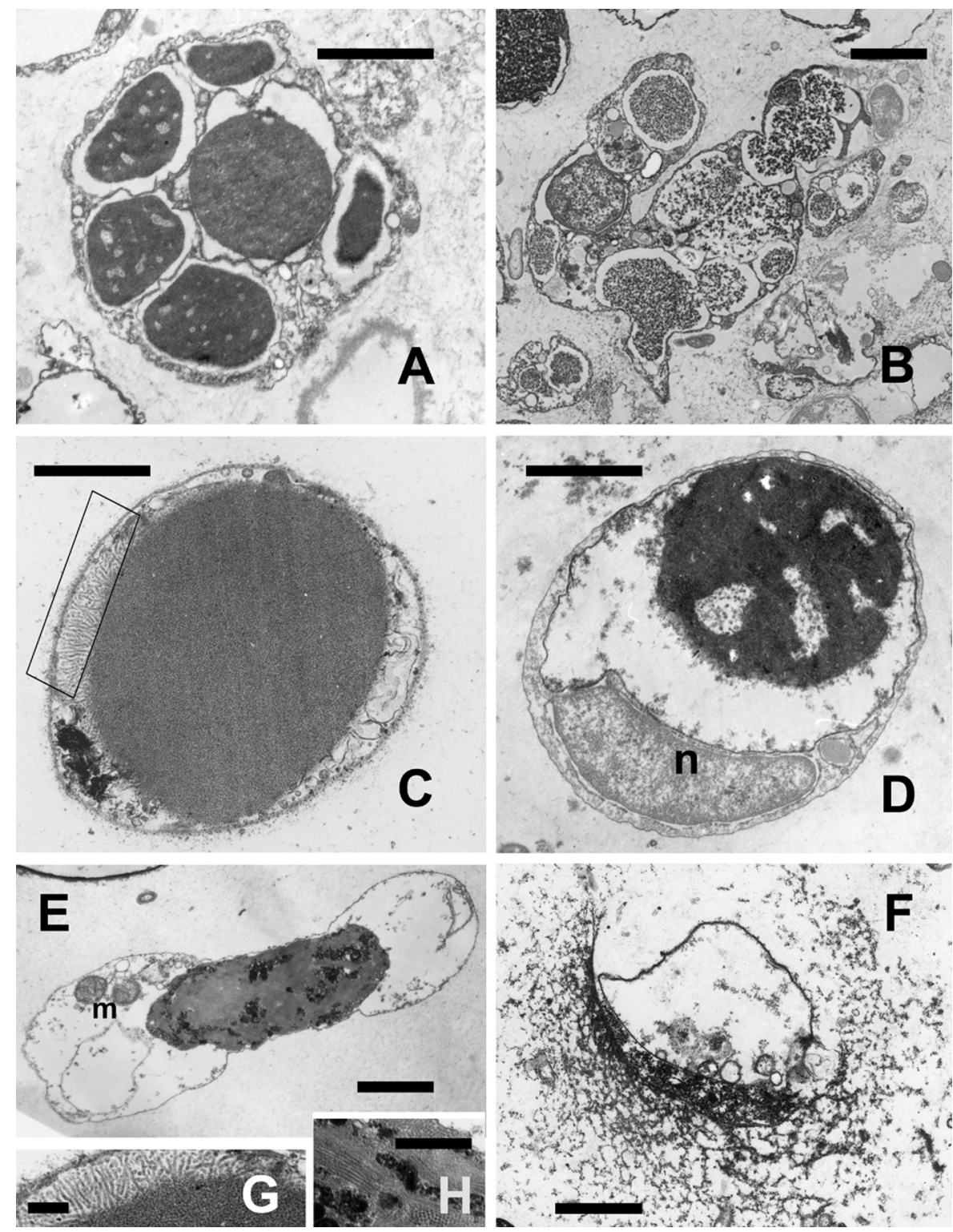

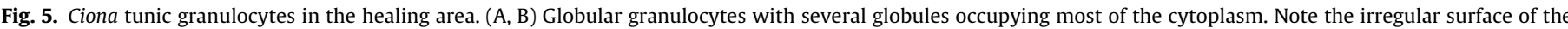

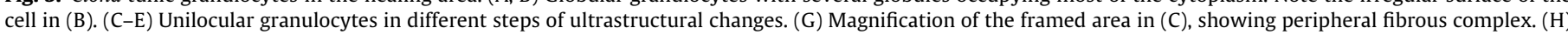

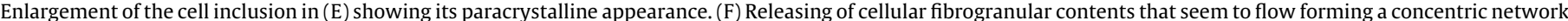
around tunic matrix. $\mathrm{m}=$ mitochondria. Bars: $\mathrm{B}, \mathrm{C}, \mathrm{E}, \mathrm{F}=2 \mu \mathrm{m} ; \mathrm{A}, \mathrm{D}=1.5 \mu \mathrm{m} ; \mathrm{G}, \mathrm{H}=0.5 \mu \mathrm{m}$.

that form aggregates. Coarse net-like structures and branching fibres covered the wound surface in Ciona tunic and electrondense fibres were aggregating to form the boundary layer. Similar features have been described in the cuticle restoration elicited by experimentally damaging operations in other ascidians such as Aplidium and Botrylloides (Hirose et al., 1995, 1997a,b). Moreover, the cuticular boundary formation with aggregates that become gradually packed is functionally and structurally similar to the new wall formation seen in the allogeneic rejection reaction in Botryllus (Hirose et al., 1990; Tanaka and Watanabe, 1973) and allograft rejection in S. plicata (Raftos, 1990). Thus aggregating fibres could induce the formation of new covering cuticle and tunic matrix.

The massive number of cells within the wounded areas in both Styela and Ciona may be due to the recruitment of haemocytes that infiltrate from blood lacunae reaching the injured area. Although in this study the mode of occurrence of this infiltration is not clarified, haemocytes can pass through the mantle epithelium probably induced by humoral factors discharged from tunic cells, as reported during the experimentally induced inflammatory-like response
(Di Bella and De Leo, 2000). It has also been shown that following injury, production of additional cells probably capable of rebuilding damaged tissue occurs in different ways such as proliferation of resident cell population or increased mitotic contribution (Di Bella and De Leo, 2010; Di Bella et al., 2005).

Active phagocytosis was evident within these areas. Many cells with cytoplasmic extensions similar to filopodia and phagocytic vacuoles engulfing bacteria or remnants of dead cells were found. Granulocytes with their clearance properties are critical components of innate immune response that involve specific mechanisms of recognition of pathogens to be eliminated. Previous studies have documented the presence of bacteria both inside the tunic and on the cuticle of Ciona (De Leo and Patricolo, 1980; De Leo et al., 1981; Groepler and Schuett, 2003) and cyanobacteria have been observed in the tunic from other ascidians (Hirose et al., 2006, 2009b). Recently, Blasiak and co-workers (2014) have analysed the intratunic resident bacterial communities. Making a comparison with the exterior bacterial groups, the authors evidenced community differences because some groups seem to be present only in the 


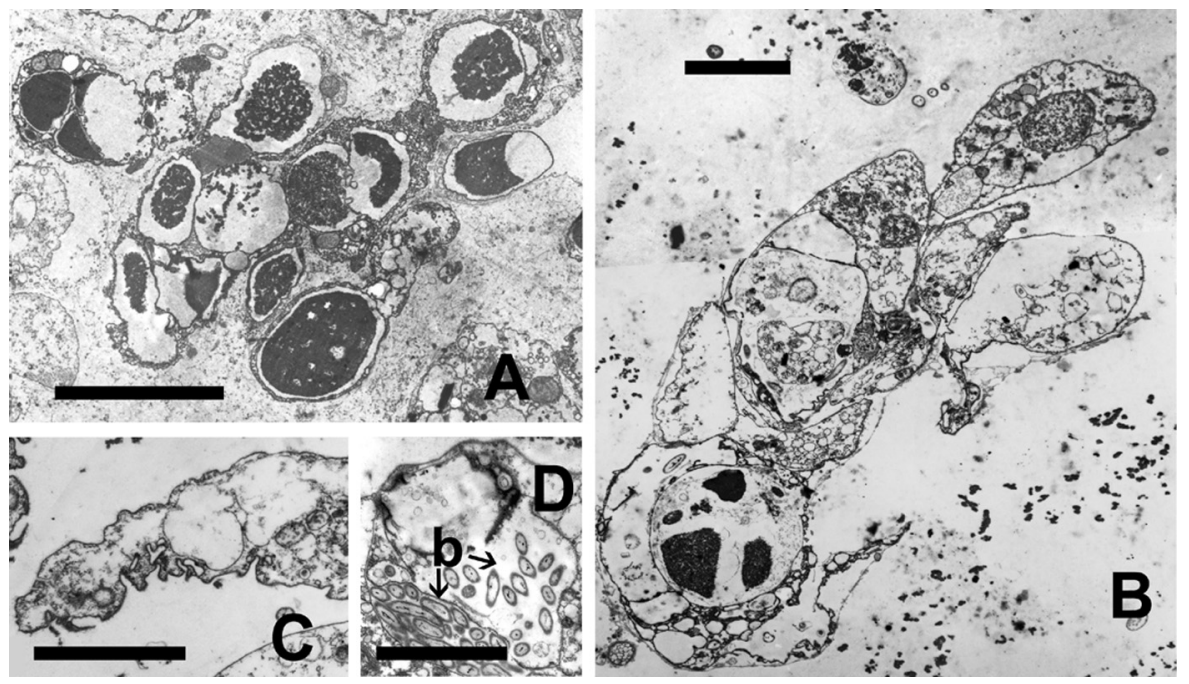

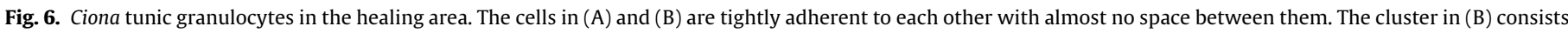

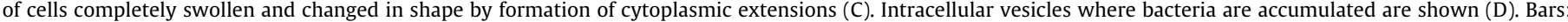
$4 \mu \mathrm{m}$.

exterior areas. In the wounded samples the observed high density of intratunical bacteria population and foreign microorganisms is possibly due to a pathogenic infection. Although it is thought there might be a mutual association between bacteria and the ascidian host, and the tunic bacterial community could protect the tunicate against fouling through the production of natural products (Kwan et al., 2012), there is evidence that some microbial cells give rise to a defensive reaction. This implies a strong selection from ascidian species. The defence reaction, at least in part, is carried out by the production of several antimicrobial peptides expressed by tunic granulocytes. Antimicrobial peptides, ubiquitously found in all kingdoms, are known to have rapid and efficient effects against microbes (Bulet et al., 2004). It has been shown that several antimicrobial peptides were released into the Ciona tunic matrix during inflammatory-like response experimentally induced (Di Bella et al., 2011) and in the naturally occurring injury sites (Di Bella et al., 2013).

As regards Styela, bacteria and protozoans, usually, are not largely present within the tunic of healthy adults; thus, their high presence in these damaged sites may be due to the bacterial infection.

Remodelling of tissue integrity is performed by immune cells present at the wound site; degranulating cells were consistently observed and the electron-dense fibrous material discharged around them may denote the involvement of tunic cells to aid the regeneration of the tunic matrix and the cuticle. The discharged contents probably rearrange the tunic matrix as observed in some colonial and solitary ascidians both during allogeneic rejection (Hirose et al., 1990; Tanaka, 1973; Tanaka and Watanabe, 1973) and during inflammatory-like response (De Leo et al., 1992); furthermore, following experimentally induced injury, many of the cells undergo drastic changes releasing their contents to become true ghosts of cells (De Leo et al., 1996, 1997). Most of cells encountered in the wounded areas of Styela were clear vesicular granulocytes; indeed, globular granulocytes showing an increase of irregular surface were the predominant cells present in Ciona damaged tunic. Clear vesicular granulocytes are amoeboid cells, with various forms and evidence of phagocytosis. They might be involved in cellular defence mechanisms and scavenging functions.

As regards the involvement of tunic cell in the healing process, the role of each type remains uncertain. Because some resident tunic cells are similar in morphology to certain types of haemocytes, at present, the ultrastructural observations in this study do not enable us to distinguish between infiltrating cells and tunic cells by their cytomorphology. Nevertheless, it could be speculated that tunic cells release chemiotactic factors that induce haemocytes infiltration.

Inflammatory cells are not only responsible for clearing the wound site from pathogens and dead cells, but through degranulation they also respond to the recognition of foreign agents and release enzymes and cytokine-like molecules. Indeed, molecules recognized by antibodies against the mammalian proinflammatory cytokines IL-1-a and TNF- $\alpha$, have been reported in several ascidian species (Ballarin et al., 2001; Cima et al., 2004; Parrinello et al., 2007; Raftos et al., 1991, 1992). Their presence increases during the rejection reaction which occurs when genetically incompatible colonies of Botryllus contact each other (Cima et al., 2006; Franchi et al., 2014) and also during inflammatory-like reaction challenged in the $C$. intestinalis body wall by inoculation with LPS (Parrinello et al., 2007). As suggested by Menin et al. (2005), cytokine-like molecules, analogously to vertebrate cytokine, are involved in the selective recruitment and activation of haemocytes in the sites of inflammation or in the wounded area. As regards $S$. plicata, it has recently been shown that histamine, a biogenic amine playing a role in the regulation of vertebrate inflammation and immunity, is stored inside granular haemocytes; it is promptly released after in vitro stimulation of haemocytes with different pathogen-associated molecules patterns (PAMPs). The massive increment in the number of haemocytes present at the site of wounding after the injection of histamine into the tunic, is consistent with the role that this molecule may play in the regulation of Styela immunity, involving the selective recruitment of effector cells into the tissues (de Barros et al., 2007; García-García et al., 2014). Moreover, the prophenoloxidase system is activated on the wound to produce melanization (Jackson et al., 1993; Johansson and Söderhall, 1989). The prophenoloxidase system is a proteolytic enzyme cascade which recognizes minuscule amounts of cell wall products from microorganisms (lipopolysaccharide, peptidoglycan and glucans) and responds to the microbes by activation of the system and the subsequent generation of immune factors (Cerenius et al., 2008). Tunicate globular granulocytes such as those called elsewhere morula cells, on contact with foreign molecules, can degranulate and release the content of their vacuoles, mainly inactive prophenoloxidase that, once active, produces melanin 
which accumulates in some areas of the tunic (Ballarin et al., 2001; Cammarata and Parrinello, 2009; Cammarata et al., 2008). Thus, different enzymatically catalysed cascades involved in clotting, melanization, and complement activation (Lavelle et al., 2010; Maldonado-Contreras and McCormick, 2011) can recruit a variety of cell types (Arizza and Parrinello, 2009; Parrinello, 1996; Vizzini et al., 2008) and induce the expression of characteristic innate immune receptors (Dishaw et al., 2011; Parrinello, 2009; Sasaki et al., 2009; Shida et al., 2003) and immunological phenomena (Melillo et al., 2006; Smith and Peddie, 1992).

Interestingly, in Ciona specimens, several tightly packed and aggregating globular granulocytes were found at the site of injury. The exhibited tight clustering is morphologically similar to the formation of cellular clumps. A stable clump is required to seal the wound and prevent the loss of haemolymph because no coagulation has been reported in the tunicate haemolymph and there is general agreement that extracellular clots do not occur (Jiang and Doolittle, 2003; Kulman et al., 2006). The aggregation of haemocytes also acts as a secondary barrier to prevent bacterial and pathogenic dissemination from the injury site. In insects and horsecrab the sequestration of bacteria seems to occur within seconds (Cerenius and Söderhäll, 2011; Lesch et al., 2007; Theopold et al., 2014). The possibility exists that lectins, functioning as cell-surface receptors, acting as opsonins, can bind to the microorganism surface by one binding site and to the cell surface by another binding site, thus forming a bridge between a phagocyte and bacteria. A large number of haemagglutinating lectins binding to a wide variety of carbohydrates have been isolated from ascidians (Green et al., 2006; Menin and Ballarin, 2008; Parrinello et al., 2007; Vasta and Marchalonis, 1983). Recently, a new member of the RBL (rhamnose binding lectin) family was isolated from the colonial ascidian Botryllus schlosseri. Its ability to agglutinate foreign particles was characterized and a multiple role in immunosurveillance and immunomodulation was hypothesized (Gasparini et al., 2008; Franchi et al., 2011). The presence in damaged areas of clumps of cellular ghosts with vesicles where bacteria are accumulated implies that cells may be involved in the clearance of cellular debris and invading microbes. Remarkably, when different Botryllus colonies are brought into contact, a strong self-nonself reaction is provoked that results in cell clumping at the sites of contact (Oren et al., 2008; Saito et al., 1994). Cell aggregation as allogeneic response, was also reported in the colonial ascidian Aplidium (Ishii et al., 2008).

In conclusion, the current work provides advances in our knowledge of $S$. plicata and $C$. intestinalis wound repair and outlines the changes that occur in their damaged tunic areas. Some of the observed features recall the allogeneic rejection reactions and the inflammatory-like reactions that occur in solitary and compound ascidians. In order to maintain host-microbial interactions after cuticle damage, mechanisms of innate response including barrier defenses, secretion of components like antibacterial peptides, recruitment of tunic cells and haemocyte infiltration, clumping, surely occur even if we are not sure which one occurs first.

Although we did not intended to provide a complete description of the events, since we could not observe the time course of these processes with precision in living specimens, the study may contribute to the debate on the evolution of innate immunity and help to show how wound healing, tissue clearing, and the reconstruction of damaged areas can occur. Wound repair is a multi-step process that involves a complex network of signals and behaviours necessary to seal the wound; therefore, future investigations should include the integration of morphological data with biochemical, molecular and physiological results and research on the possible role of different genes simultaneously involved in the key immune defense mechanisms.

\section{Acknowledgments}

We thank the Stazione Zoologica Anton Dohrn (Naples-Italy) for providing animals. The authors are grateful to Dr. Sheila McIntyre for polishing the English. M. A. Di Bella and G. De Leo are supported by the Italian Ministero della Istruzione, dell'Università e della Ricerca (MIUR).

\section{References}

Arizza, V., Parrinello, N., 2009. Inflammatory hemocytes in Ciona intestinalis innate immune response. Invertebr. Surviv. J. 6, S58-S66.

Ballarin, L., Franchini, A., Ottaviani, E., Sabbadin, A., 2001. Morula cells as the main immunomodulatory haemocytes in ascidians: evidences from the colonial species Botryllus schlosseri. Biol. Bull. 201, 59-64.

Bulet, P., Stocklin, R., Menin, L., 2004. Anti-microbial peptides: from invertebrates to vertebrates. Immunol. Rev. 198, 169-184.

Burighel, P., Cloney, R.A., 1997. Urochordata: Ascidiacea. In: Harrison, F.W., Ruppert, E.E.(Eds.), Microscopical Anatomy of Invertebrates, vol. 15. Wiley-Liss, New York, pp. 221-347.

Blasiak, L.C., Zinder, S.H., Buckley, D.H., Hill, R.T., 2014. Bacterial diversity associated with the tunic of the model chordate Ciona intestinalis. ISME J. 8, 309-320.

Cammarata, M., Parrinello, N., 2009. The ascidian prophenoloxidase activating system. Invertebr. Surviv. J. 6, 67-76.

Cammarata, M., Arizza, V., Cianciolo, C., Parrinello, D., Vazzana, M., Vizzini, A., Salerno, G., Parrinello, N., 2008. The prophenoloxidase system is activated during the tunic inflammatory reaction of Ciona intestinalis. Cell Tissue Res. 333, 481-492.

Cerenius, L., Söderhäll, K., 2011. Coagulation in invertebrates. J. Innate Immun. 3, 3-8.

Cerenius, L., Lee, B.L., Söderhäll, K., 2008. The proPO-system: pros and cons for its role in invertebrate immunity. Trends Immunol. 29, 263-271.

Cima, F., Sabbadin, A., Ballarin, L., 2004. Cellular aspects of allorecognition in the compound ascidian Botryllus schlosseri. Dev. Comp. Immunol. 28, 881-889.

Cima, F., Sabbadin, A., Zaniolo, G., Ballarin, L., 2006. Colony specificity and chemiotaxis in the compound ascidian Botryllus schlosseri. Comp. Biochem. Physiol. 145, 376-382.

de Barros, C.M., Andrade, L.R., Allodi, S., Viskov, C., Mourier, P.A., Cavalcante, M.C., Straus, A.H., Takahashi, H.K., Pomin, V.H., Carvalho, V.F., Martins, M.A., Pavão, M.S., 2007. The hemolymph of the ascidian Styela plicata (Chordata-Tunicata) contains heparin inside basophil-like cells and a unique sulfated galactoglucan in the plasma. J. Biol. Chem. 282, 1615-1626.

De Leo, G., 1992. Ascidian hemocytes and their involvement in defence reactions. Boll. Zool. 59, 195-213.

De Leo, G., Patricolo, E., 1980. Blue-green algalike cells associated with the tunic of Ciona intestinalis L. Cell Tissue Res. 212, 91-98.

De Leo, G., Patricolo, E., D’Ancona Lunetta, G., 1977. Studies on the fibrous components of the test of Ciona intestinalis Linnaeus. I. Cellulose-like polysaccharide. Acta Zool. (Stockh.) 58, 135-141.

De Leo, G., Patricolo, E., Frittitta, G., 1981. Fine structure of the tunic of Ciona intestinalis L. II. Tunic morphology, cell distribution and their functional importance. Acta Zool. (Stockh.) 62, 259-271

De Leo, G., Parrinello, N., Di Bella, M.A., 1992. Structural changes in granulocytes involved in the lysis of the tunic during inflammatory-like reaction induced in Ciona intestinalis (Tunicata, Ascidiacea). Eur. Arch. Biol. 103, 113-119.

De Leo, G., Parrinello, N., Parrinello, D., Cassarà, G., Di Bella, M.A., 1996. Encapsulation response of Ciona intestinalis (Ascidiacea) to intratunical erythrocyte injection. I. The inner capsular architecture. J. Invertebr. Pathol. 67, 205-212.

De Leo, G., Parrinello, N., Parrinello, D., Cassarà, G., Russo, D., Di Bella, M.A., 1997. Encapsulation response of Ciona intestinalis (Ascidiacea) to intratunical erythrocyte injection. II. The outermost inflamed area. J. Invertebr. Pathol. 69, 14-23.

Delsuc, F., Brinkmann, H., Chorrot, D., Hervé, P., 2006. Tunicate and not cephalochordates are the closest living relatives of vertebrates. Nature 439, 965-968.

Di Bella, M.A., De Leo, G., 2000. Hemocyte migration during inflammatory-like reaction of Ciona intestinalis (Tunicata, Ascidiacea). J. Invertebr. Pathol. 76, 105-111.

Di Bella, M.A., De Leo, G., 2010. Contribution of microscopy to the study of proliferating blood cells in Ciona intestinalis immune response. In: Méndez-Vilas, A. Díaz, J. (Eds.), Microscopy: Science, Technology, Applications and Education, vol. 1, pp. 111-115.

Di Bella, M.A., Cassarà, G., Russo, D., De Leo, G., 1998. Cellular components and tunic architecture of the solitary ascidian Styela canopus (Stolidobranchiata). Tissue Cell 30, 352-359.

Di Bella, M.A., Carbone, M.C., De Leo, G., 2005. Aspects of cell production in mantle tissue of Ciona intestinalis L. (Tunicata, Ascidiacea). Micron 36, 477-481.

Di Bella, M.A., Fedders, H., Leippe, M., De Leo, G., 2011. Localization of antimicrobial peptides in the tunic of Ciona intestinalis (Ascidacea, Tunicata) and their involvement in local inflammatory-like reactions. Results Immunol. 1, 70-75.

Di Bella, M.A., Fedders, H., Leippe, M., De Leo, G., 2013. Antimicrobial peptides in the tunic of Ciona intestinalis (Tunicata). In: Méndez-Vilas, A. (Ed.), Worldwide Research Efforts in the Fighting Against Microbial Pathogens: From Basic Research to Technological Developments. BrownWalker Press, Boca Raton, USA, pp. 63-67. 
Dishaw, L.J., Giacomelli, S., Melillo, D., Zucchetti, I., Haire, R.N., Natale, L., Russo, N.A., De Santis, R., Litman, G.W., Pinto, M.R., 2011. A role for variable regioncontaining chitin-binding proteins (VCBPs) in host gut-bacteria interactions. Proc. Natl. Acad. Sci. U.S.A. 108, 16747-16752.

Franchi, N., Schiavon, F., Carletto, M., Gasparini, F., Bertoloni, G., Tosatto, S.C., Ballarin, L., 2011. Immune roles of a rhamnose-binding lectin in the colonial ascidian Botryllus schlosseri. Immunobiology 216, 725-736.

Franchi, N., Hirose, E., Ballarin, L., 2014. Cellular aspects of allorecognition in the compound ascidian Botrylloides simodiensis. Invertebr. Surviv. J. 11, 219-223.

García-García, E., Gómez-González, N.E., Meseguer, J., García-Ayala, A., Mulero, V., 2014. Histamine regulates the inflammatory response of the tunicate Styela plicata. Dev. Comp. Immunol. 46, 382-391.

Gasparini, F., Franchi, N., Spola, B., Ballarin, L., 2008. Novel rhamnose-binding lectins from the colonial ascidian Botryllus schlosseri. Dev. Comp. Immunol. 32, 1177-1191.

Goodbody, I., 1974. The physiology of ascidians. In: Russel, F.S., Yonge, M. (Eds.), Advances in Marine Biology, vol. 12. Academic Press, London, pp. 1-149.

Green, P., Luty, A., Nair, S., Radford, J., Raftos, D., 2006. A second form of collagenous lectin from the tunicate, Styela plicata. Comp. Biochem. Physiol. 144, 343-350.

Groepler, W., Schuett, C., 2003. Bacterial community in the tunic matrix of a colonial ascidian Diplosoma migrans. Helgoland Mar. Res. 57, 139-143.

Hirose, E., 2009a. Ascidian tunic cells: morphology and functional diversity of free cells outside the epidermis. Invertebr. Biol. 128, 83-96.

Hirose, E., Saito, Y., Watanabe, H., 1990. Allogeneic rejection induced by cut surface contact in the compound ascidian Botrylloides simodensis. Invertebr. Reprod. Dev. 17, 159-164.

Hirose, E., Saito, Y., Watanabe, H., 1995. Regeneration of the tunic cuticle in the compound ascidian, Botrylloides simodensis. Dev. Comp. Immunol. 19, 143-151.

Hirose, E., Saito, Y., Watanabe, H., 1997a. Subcuticular rejection: an advanced mode of the allogeneic rejection in the compound ascidians Botrylloides simodensis and B. fuscus. Biol. Bull. 192, 53-61.

Hirose, E., Taneda, Y., Ishii, T., 1997b. Two modes of cuticle formation in a colonial ascidian Aplidium yamazii. Dev. Comp. Immunol. 21, 25-34.

Hirose, E., Hirose, M., Neilan, B.A., 2006. Localization of symbiotic cyanobacteria in the colonial ascidian Tridemnidum miniatum (Didemnidae; Ascidiacea).Zool. Sci. 23, 435-442.

Hirose, E., Neilan, B.A., Scmidt, E.W., Murakami, A., 2009b. Enigmatic life and evolution of Prochloron and related cyanobacteria inhabiting colonial ascidians. In: Gault, P.M., Marler, H.J. (Eds.), Handbook on Cyanobacteria. Bacteriology Developments Series. Nova Science Publishers, Inc., pp. 161-189.

Hirose, E., Ohtake, S.-I., Azumi, K., 2009c. Morphological characterization of the tunic in the edible ascidian, Halocynthia roretzi (Drasche), with remarks on soft tunic syndrome in aquaculture. J. Fish Dis. 32, 433-445.

Ishii, T., Hirose, E., Taneda, Y., 2008. Tunic phagocytes are involved in allorejection reaction in the colonial tunicate Aplidium yamazii (Polyclinidae, Ascidiacea). Biol. Bull. 214, 145-152.

Jackson, A.D., Smith, V.J., Peddie, C.M., 1993. In vitro phenoloxidase activity in the blood of Ciona intestinalis and other ascidians. Dev. Comp. Immunol. 17, 97-108.

Jiang, Y., Doolittle, R.F., 2003. The evolution of vertebrate blood coagulation as viewed from a comparison of puffer fish and sea squirt genomes. Proc. Natl. Acad. Sci. U.S.A. 100, 7527-7532.

Johansson, M.W., Söderhall, K., 1989. Cellular immunity in crustaceans and the proPO system. Parasitol. Today 5, 171-176.

Kwan, J.C., Donia, M.S., Hanb, A.W., Hirose, E., Haygood, M.G., Schmidt, E.W., 2012. Genome streamlining and chemical defense in a coral reef symbiosis. Proc. Natl. Acad. Sci. U.S.A. 109, 20655-20660.

Kulman, J.D., Harris, J.E., Nakazawa, N., Ogasawara, M., Satake, M., Davie, E.W., 2006. Vitamin K-dependent proteins in Ciona intestinalis, a basal chordate lacking a blood coagulation cascade. Proc. Natl. Acad. Sci. U.S.A. 103, 15794-15799.

Lavelle, E.C., Murphy, C., O'Neill, L.A., Creagh, E.M., 2010. The role of TLRs, NLRs, and RLRs in mucosal innate immunity and homeostasis. Mucosal Immunol. 3, 17-28.

Lesch, C., Goto, A., Lindgren, M., Bidla, G., Dushay, M.S., Theopold, U., 2007. A role for hemolectin in coagulation and immunity in Drosophila melanogaster. Dev. Comp. Immunol. 31, 1255-1263.

Maldonado-Contreras, A.L., McCormick, B.A., 2011. Intestinal epithelial cells and their role in innate mucosal immunity. Cell Tissue Res. 343, 5-12.

Melillo, D., Sfyroera, G., De Santis, R., Graziano, R., Marino, R., Lambris, J.D., Pinto, M.R., 2006. First identification of a chemotactic receptor in an invertebrate species: structural and functional characterization of Ciona intestinalis C3a receptor. J Immunol. 177, 4132-4140.

Menin, A., Ballarin, L., 2008. Immunomodulatory molecules in the compound ascidian Botryllus schlosseri: evidence from conditioned media. J. Invertebr. Pathol. 99, 275-280.

Menin, A., del Favero, M., Cima, F., Ballarin, L., 2005. Release of phagocytosisstimulating factor(s) by morula cells in a colonial ascidian. Mar. Biol. 148 225-230.

Oren, M., Escande, M.I., Paz, G., Fishelson, Z., Rinkevich, B., 2008. Urochordate histoincompatible interactions activate vertebrate-like coagulation system components. PLoS ONE 3, e3123.

Parrinello, N., 1996. Cytotoxic activity of tunicate hemocytes. In: Rinkevich, B. Müller, W.E.G. (Eds.), Invertebrate Immunology. Springer-Verlag, Berlin, pp. $190-217$.

Parrinello, N., 2009. Focusing on Ciona intestinalis (Tunicata) innate immune system. Evolutionary implications. Invertebr. Surviv. J. 6, S46-S57.

Parrinello, N., Patricolo, E., 1984. Inflammatory-like reaction in the tunic of Ciona intestinalis (Tunicata), II. Capsule components. Biol. Bull. 167, 238-250.

Parrinello, N., Patricolo, E., Canicattì, C., 1977. Tunicate immunobiology, I. Tunic reaction of Ciona intestinalis L. to erythrocyte injection. Boll. Zool. 44, 373-381.

Parrinello, N., Patricolo, E., Canicattì, C., 1984. Inflammatory-like reaction in the tunic of Ciona intestinalis (Tunicata), I. Encapsulation and tissue injury. Biol. Bull. 167 229-237.

Parrinello, N., Arizza, V., Cammarata, M., Giaramita, F.T., Pergolizzi, M., Vazzana, M. Vizzini, A., Parrinello, D., 2007. Inducible lectins with galectin properties and human IL $1 \alpha$ epitopes opsonize yeast during the inflammatory response of the ascidian Ciona intestinalis. Cell Tissue Res. 329, 379-390.

Patricolo, E., De Leo, G., 1979. Studies on the fibrous components of the test of Ciona intestinalis Linnaeus, II. Collagen-elastin-like protein. Acta Zool. (Stockh.) 60 259-269.

Raftos, D., 1990. The morphology of allograft rejection in Styela plicata (Urochordata: Ascidiacea). Cell Tissue Res. 261, 389-396.

Raftos, D.A., Cooper, E.L., Habicht, G.S., Beck, G., 1991. Invertebrate cytokines: tunicate cell proliferation stimulated by an interleukin 1-like molecule. Proc. Natl. Acad. Sci. U.S.A. 88, 9518-9522.

Raftos, D.A., Cooper, E.L., Stillman, D.L., Habicht, G.S., Beck, G., 1992. Invertebrate cytokines II: release of interleukin-1-like molecules from tunicate hemocytes stimulated with zymosan. Lymphokine Cytokine Res. 11, 235-240.

Saito, Y., Hirose, E., Watanabe, H., 1994. Allorecognition in compound ascidians. Int J. Dev. Biol. 38, 237-247.

Sasaki, N., Ogasawara, M., Sekiguchi, T., Kusumoto, S., Satake, H., 2009. Toll-like receptors of the ascidian Ciona intestinalis: prototypes with hybrid functionalities of vertebrate toll-like receptors. J. Biol. Chem. 284, 27336-27343.

Shida, K., Terajima, D., Uchino, R., Ikawa, S., Ikeda, M., Asano, K., Watanabe T., Azumi, K., Nonaka, M., Satou, Y., Satoh, N., Satake, M., Kawazoe, Y. Kasuya, A., 2003. Hemocytes of Ciona intestinalis express multiple genes involved in innate immune host defense. Biochem. Biophys. Res. Commun. 302, 207-218.

Smith, V.J., Peddie, C.M., 1992. Cell cooperation during host defence in the solitary tunicate Ciona intestinalis (L). Biol. Bull. 183, 211-219.

Tanaka, K., 1973. Allogeneic inhibition in a compound ascidian, Botryllus primigenus Oka. II. Cellular and humoral responses in nonfusion reaction. Cell. Immunol. 7 $427-443$

Tanaka, K., Watanabe, H., 1973. Allogeneic inhibition in a compound ascidian, Botryllus primigenus Oka. I. Processes and features of "nonfusion" reaction. Cell. Immunol. 7, 410-426.

Theopold, U., Krautz, R.S., Dushay, M., 2014. The Drosophila clotting system and its messages for mammals. Dev. Comp. Immunol, 42, 42-46.

Vasta, G.R., Marchalonis, J.J., 1983. In: Bog-Hanse, T.C. (Ed.), Lectins: Biology, Biochemistry, Clinical Biochemistry, vol. 3. Walter De Gruyter, Berlin, pp. 461-468.

Vizzini, A., Pergolizzi, M., Vazzana, M., Salerno, G., Di Sano, C., Macaluso, P., Arizza, V., Parrinello, D., Cammarata, M., Parrinello, N., 2008. FACIT collagen (1alpha-chain) is expressed by hemocytes and epidermis during the inflammatory response of the ascidian Ciona intestinalis. Dev. Comp. Immunol. 32, 682-692. 